\title{
A Waldenström-macroglobulinaemia és betegségre szabott kezelése
}

\author{
Szemlaky Zsuzsanna dr. - Mikala Gábor dr. \\ Egyesített Szent István és Szent László Kórház-Rendelőintézet, \\ Hematológiai és Őssejt-transzplantációs Osztály, Budapest
}

\begin{abstract}
A Waldenström-féle macroglobulinaemia egy jellemzően a csontvelőben terjedő lymphoplasmocytás lymphoma és következményes monoklonális IgM-hiperszekréció okozta klinikai tünetegyüttes. A közelmúlt eredményei rámutattak, hogy a betegség legalább három eltérő patobiológiájú és klinikai viselkedésű formájában jelentkezhet. A MYD88 95-97\%-os gyakoriságú mutációi mellett 30-40\%-os gyakorisággal megjelenhetnek CXCR4-mutációk, 17\%-ban ARIDlA-mutációk és 10\% körüli gyakorisággal CD79B-mutációk. A CXCR-jelátvitel képes a MYD88-aktiváció fokozta tumorszuppresszorgén-múködés elnémítására. A MYD88- és CXCR4-mutációk együttes előfordulása nagyobb tumortömeget, kezeléskor lassabban kialakuló és kevésbé mély választ eredményez, gyakoribb rezisztenciával. Összefoglalónkban a legújabb adatok birtokában kívánunk támpontot nyújtani a szimptomatikus betegség kezelésekor megkívánt kezelési protokoll megválasztásához.
\end{abstract}

Orv Hetil. 2017; 158(41): 1604-1614.

Kulcsszavak: Waldenström-macroglobulinaemia, MYD88, CXCR4, tumorszuppresszor, terápia

\section{Waldenström's macroglobulinemia and its individualized therapy options}

Waldenström's macroglobulinaemia is a form of lymphoplasmocytic lymphoma that preferentially localizes to the bone marrow and causes a special syndrome characterized by monoclonal IgM hypersecretion. Recent results point to the fact that this disease has at least three different pathobiological forms with different clinical presentation. While mutations of MYD88 occur in 95-97\% of the cases, there are CXCR4 mutations in 30-40\%, ARIDlA mutations in $17 \%$ and CD79B mutations in approximately $10 \%$ of afflicted individuals. CXCR pathway signaling is able to transcriptionally silence tumor suppressors induced by MYD88 activation. Patients with mutated MYD88 and CXCR4 present with higher tumor burden, slower developing and less deep response upon therapy with more frequent resistance. In this review, based on the most recent data, a treatment selection advice is provided for the therapy of symptomatic patients.

Keywords: Waldenström's macroglobulinemia, MYD88, CXCR4, tumorsuppressor, therapy

Szemlaky Zs, Mikala G. [Waldenstrom's macroglobulinaemia and its individualized therapy options]. Orv Hetil. 2017; 158(41): 1604-1614.

(Beérkezett: 2017. augusztus 2.; elfogadva: 2017. szeptember 4.)

\section{Rövidítések}

ASCT $=$ (autologous stem cell transplantation $)$ autológ össejttranszplantáció; BRD = bortezomib + rituximab + dexamethason; IPSSWM = (International prognostic scoring system for Waldenström macroglobulinemia) (Waldenström-macroglobulinaemia nemzetközi prognosztikai rendszere); MGUS = monoclonal gammopathy of undetermined significance (idio- pathiás monoklonális gammopathia); $\mathrm{MM}=$ myeloma multiplex; OGYÉI = Országos Gyógyszerészeti és Élelmezés-egészségügyi Intézet; POEMS-szindróma = polyneuropathia, organomegalia, endocrinopathia, monoclonalis protein, skin = bőrtünetek; SMM = smouldering myeloma; SWM = smouldering Waldenström-macroglobulinaema; $\mathrm{WM}=$ Waldenströmféle macroglobulinaemia 
A monoklonális gammopathiák spektrumába klonális plazmasejtes betegségek tartoznak, mint az MGUS (idiopathiás monoklonális gammopathia), a myeloma multiplex (MM) és a Waldenström-féle macroglobulinaemia (WM). Az MGUS-t premalignus állapotnak tartjuk, amelynek három típusát különíthetjük el: IgM MGUS, non-IgM MGUS (IgA- és IgG-MGUS) és könnyưláncMGUS. A malignus betegségbe történő progresszió legtöbbször tünetmentes, úgynevezett smouldering stádiumon keresztül történik, így megkülönböztetünk smouldering myelomát (SMM) és smouldering Waldenström-macroglobulinaemát (SWM) is. IgM MGUSból Waldenström-macroglobulinaemia, a non-IgM MGUS-ból myeloma multiplex, míg a könnyưláncMGUS-ból könnyúlánc-myeloma alakulhat ki. Az MGUS minden formájából kialakulhat AL-amyloidosis vagy egyéb non-Hodgkin-lymphoma, amely mindenkor fontos differenciáldiagnosztikai tényező. A WM az MGUS-sal szemben ritka megbetegedés, IgM monoklonális protein szekréciójával járó B-sejtes, lymphoplasmocytás lymphoma, amely a legtöbb esetben krónikus, indolens lefolyású betegség. Főbb tünetei a monoklonális fehérje jelenlétére és a lymphoma csontvelői infiltrációjára vezethetőek vissza. A tünetek megjelenése leggyakrabban a daganatellenes terápia megkezdésének indikációját is jelenti. A betegség etiológiája ismeretlen, de a közelmúltban felfedezett betegségre specifikus pontmutációk vizsgálata a patogenezis mélyebb megértését tették lehetővé. A terápiás lehetőségek szerteágazóak. A megfelelő kezelés kiválasztását alapvetően a klinikai tünetek, a tumortömeg, a beteg életkora és az esetlegesen tervezett őssejtátültetés lehetősége befolyásolják. A betegséget jelenleg nem tudjuk meggyógyítani. A diagnózistól számított átlagos túlélés körülbelül nyolc év, de a transzplantáció megfelelő időzítésével, főként fiatalabb betegeknél, ennél lényegesen jobb eredmények is elérhetőek. A magyar nyelvű szakirodalomban 2016/2017 fordulóján Tímár Botond [1], illetve Mucsi Orsolya és Nagy Zsolt [2] tollából kiváló összefoglalók jelentek meg a WM-ról, jelen cikkünkben - ettől eltérő módon - a legújabb ismereteket is integrálva egyrészt a molekuláris eltérések terápiás következményeit, másrészt pedig a hazai terápiás lehetőségeket is figyelembe véve mutatjuk be ezt a sokarcú betegséget.

\section{A betegség molekuláris genetikája és patofiziológiája}

A WM férfi predominanciájú betegség, a férfi:nő arány 2:1. A betegség nemcsak férfiakban, hanem askenázi zsidó származásúaknál is gyakoribb [3], valamint jól ismert a családi halmozódás is (egy vizsgálatban a betegek negyedének volt B-sejtes malignitásban szenvedő rokona) [3]. A genetikus prediszpozíció oka még nem ismert, ugyanakkor bizonyos, hogy a familiáris WM terápiás válasza a sporadikus formáét alulmúlja [4].
Legrégebb óta ismert a 6q-deletiók kóroki szerepe ebben a betegségben, amely diagnosztikusan hasznos lehet az IgM-myelomától való elkülönítésben, ahol az $\operatorname{IgH}-\mathrm{t}$ érintő transzlokációk, elsősorban a $\mathrm{t}(11 ; 14)$ a jellemző citogenetikai eltérés [5-7]. A 6q-deletio következtében többek között az NFKB-szignalizációt moduláló (TNFA1P3, HIVEP2), a Bcl-2 családba tartozó (BCLAF1), apoptózist szabályozó (FOXO3), BTK-inhibitor (IBTK), plazmasejt-differenciációt szabályozó (PRDMl) és ARIDlB gének haploinsufficientiája következik be, de pontos kóroki szerepük ma még nem világos [8].

Míg a citogenetikai eredmények nem vezettek a betegség alapjainak jobb megismeréséhez, a közelmúlt új generációs szekvenálási technológiái fontos új adatokkal szolgáltak a WM természetének megismeréséhez, mind a szomatikus mutációk, mind pedig fontos szabályozógéneket érintő kópiaszám-eltérések szintjén. Elsőként a MYD88 L265P mutációját fedezték fel ebben a betegségben [9]. A MYD88 egy adaptor fehérje, amely a Tolllike receptorokkal és az IL-1-receptorcsalád tagjaival történő kölcsönhatást követően homodimerizálódik, majd további fehérjékkel összekapcsolódva egy intracelluláris fehérjekomplexumot, úgynevezett Myddoszómát képez. A Myddoszóma az NFkB-szignálút fontos aktivátora. WM-ben a BTK és az IRAKl/IRAK4 intracitoplazmatikus proteinkinázok jelentik az NFkB szignalizáció legfontosabb aktivátorát, a Myddoszóma mindkét jelátvitelnek részese [10]. Mi több, az IL-6 jelátviteli rendszerében szerepet játszó haemopoeticus sejt tirozinkináz $(\mathrm{HCK})$ is növekedési és túlélési szignált biztosít a BTK-, PI3K/Akt és MAPK-útvonalak segítségével, a Myddoszóma közremúködését igénybe véve (l. ábra).

WM-ben a MYD88 L265P-mutáció az esetek 90\%ában kimutatható, ritkábban fordul elő az S219C-, az M232T- és az S243N-mutáció [11]. A MYD88-mutáció kimutatása a WM diagnózisának egyik alappillérévé vált, jelentősen megkönnyítve a betegség klinikai követését, különös tekintettel az atípusos megjelenési formákra (például Bing-Neel-szindróma: a betegség központi idegrendszeri megjelenése) [12]. A 3p kromoszómarégió genetikai változásai kapcsán leírták a MYD88-mutált szakasz amplifikációját, a vad típusú MYD88 allél deletióját, illetve uniparentalis diszómiáját, ami MYD88-mutáns homozigóciához vezet. Klinikai szempontból érdekes, hogy a homozigóta MYD88-mutáció jobb ibrutinibre adott válasz előhírnöke [13], a Myddoszóma konstans szignalizációjához történő tumorbiológiai addikció jeleként. A MYD88-mutáció jelenléte/hiánya a WM két különböző klinikai megjelenési formáját is takarhatja: MYD88-mutáció-negatív betegségben a csontvelői infiltráció jellemzően enyhébb és az IgM-szintek is alacsonyabbak. Ennek ellenére a teljes túlélés a MYDmutációkra negatív csoportban kedvezőtlenebb, a betegség okozta halálozás rizikója körükben 10-szeres [14].

A WM-betegek 40\%-ában a CXCR4 fehérje C-terminális doménjét kódoló régió nonszenz és leolvasásikeret- 


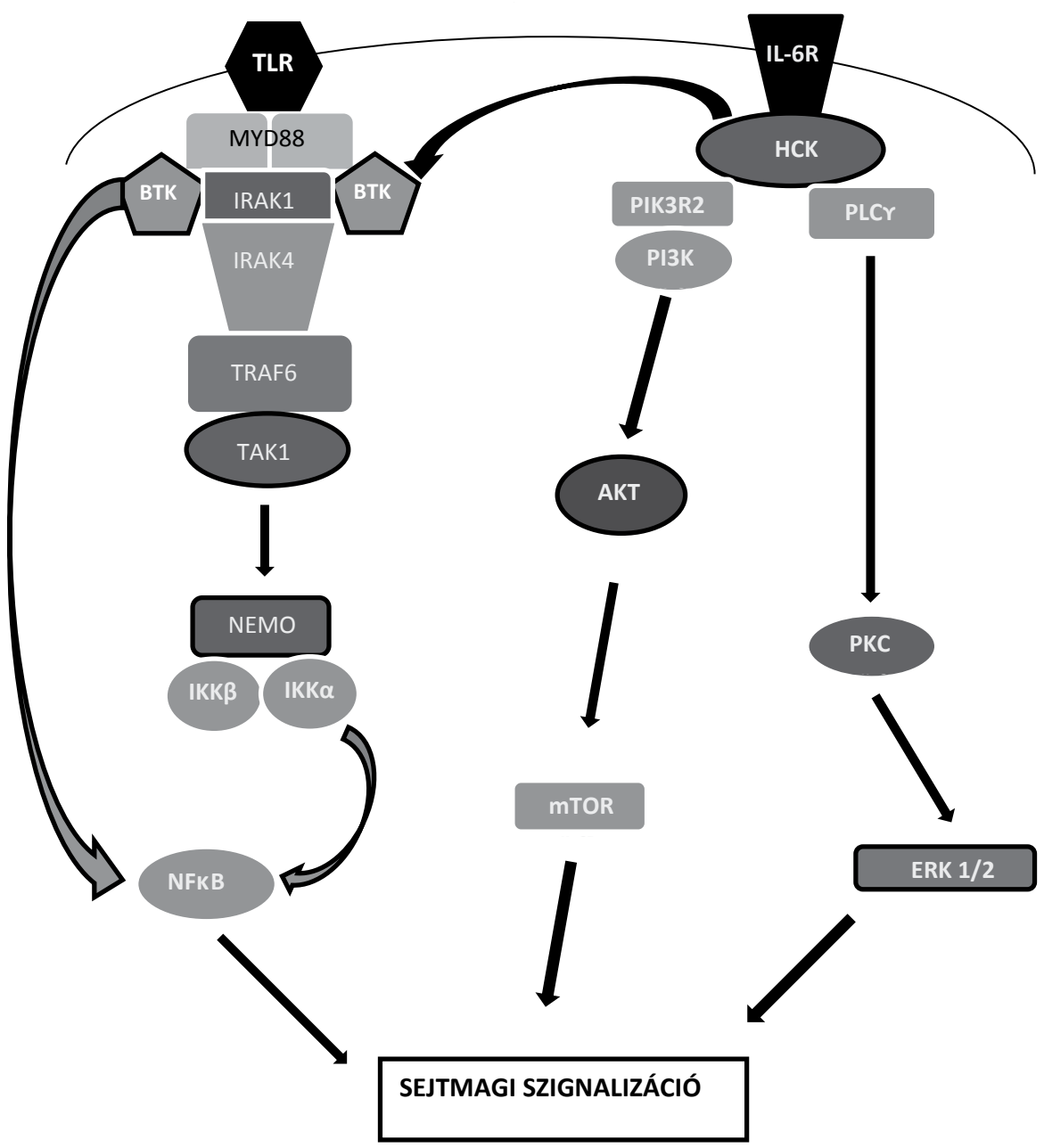

1. ábra

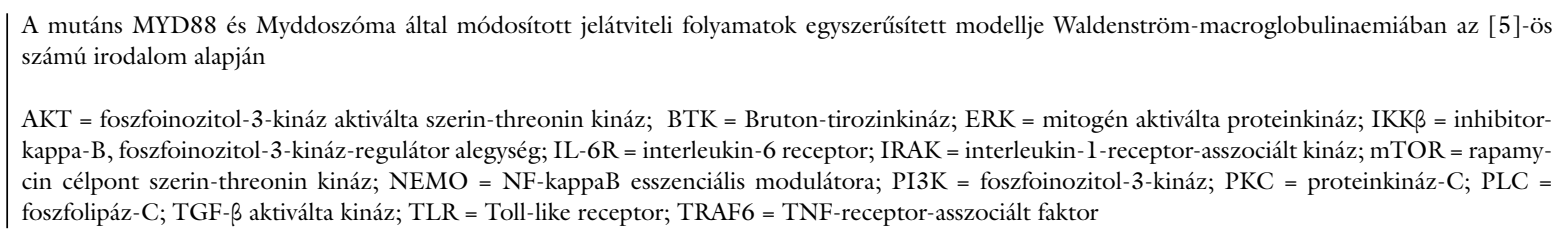

módosító (frameshift) mutációi detektálhatóak [15]. WM-ben 30-nál is többféle CXCR4-mutációt írtak le, amelyek közös jellemzője negatív regulátor (foszforilálható) szerinti oldalláncok elvesztése. A következményesen elmaradó negatív visszacsatolás miatt folyamatos szignalizáció következik be a PI3K/Akt és MAPK-útvonalakon. A CXCR4 fenti mutációit WHIM-mutációknak is szokás nevezni, mert hasonló csíravonalbeli mutációkat írtak le WHIM-szindrómában (autoszomális domináns módon megjelenő szemölcsök, hypogammaglobulinaemia, infekciók és myelocathexis). Ebben a szindrómában a CXCR4-mutációk hatására bekövetkező folyamatos jelátvitel a lymphocyták fejlődési károsodásához, valamint a neutrophil sejtek csontvelői retenciójához (myelocathexis) vezet [16]. WM-ben a CXCR4mutációk jellemzően szubklonálisak, és egy betegben többféle CXCR4-mutáns szubklón is jelen lehet, ám csaknem minden esetben MYD88-mutációhoz másodla- gosan társult formában [17]. A CXCR-jelátvitel képes a MYD88-aktiváció fokozta tumorszuppresszorgén-múködés elnémítására, az érintett sejtek számára túlélési előnyt biztosítva. CXCR4-mutáció esetén a klinikai képben ritkább a nyirokcsomó-megnagyobbodás és jelentősebb a csontvelői érintettség mértéke, magasabb a diagnóziskori IgM-szint. A CXCR4-mutációk jelenléte a túlélést valószínúleg nem befolyásolja. In vitro kultúrákban a CXCR4-mutáció többféle, WM-ben használatos tumorellenes szerrel szemben csökkent érzékenységet okozhat (bendamustin, fludarabin, bortezomib, idelalisib és ibrutinib). In vitro ez a kedvezőtlen hatás CXCR4gátlókkal felfüggeszthetőnek bizonyult [18].

A WM-betegek mintegy 17\%-ában ARIDlA szomatikus mutációk azonosíthatóak. A mutációk következtében a fehérje rövidülése következik be. Az ARIDlA a kromatin szerkezetét szabályozó, a DNS-hiszton kölcsönhatást befolyásolni képes SWI/SNF családba tartozó ATP-kötő fehérje, daganatbiológiai szempontból 
valószínúleg a TP53 múködését szabályozó tumorszuppresszor. WM klinikai képében az ARIDlA-mutáció jelenléte nagyobb diagnóziskori csontvelői érintettséget, alacsonyabb HGB-értéket és thrombocytaszámot eredményez [5].

A CD79A/CD79B fehérjék a B-sejt-receptor-jelátviteli út alkotóelemei, az Ig-nehézlánccal kapcsolódva vesznek részt a BCR-irányított szignálútban. Mind a CD79A-, mind a CD79B-mutáció 8-12\%-os gyakorisággal előfordulhat WM-ben, többnyire MYD88-mutációt kísérően. E mutációk és a CXCR4 mutációi egymást kölcsönösen kizárónak tűnnek [15]. Klinikum tekintetében a CD79B-mutáció a betegség transzformációjára hajlamosítani látszik, de ez még egyetlen centrumból származó és megerősítésre váró megfigyelés [19].

\section{A betegség epidemiológiája és prognózisa}

A Waldenström-macroglobulinaemia ritka megbetegedés, hazai összesített adatok, sajnos, nem állnak rendelkezésre. Amerikai adatok alapján a betegség incidenciája 3/1 000000 fó évente, a betegek átlagéletkora a diagnóziskor 73 év (23-98 év), a 40 év alattiak aránya kevesebb mint 1\% [20]. A betegség jelenleg gyógyíthatatlan. A diagnózistól, illetve a kezelés megkezdésének időpontjától számított átlagos túlélési idő az utóbbi évtizedben

1A táblázat |A Waldenström-macroglobulinaemia eredeti nemzetközi prog nosztikai besorolása az IPSSWM alapján

\begin{tabular}{ll}
\hline Prognosztikai faktorok: & \\
\hline Életkor & $\geq 65 \mathrm{év}$ \\
Hemoglobin & $\leq 115 \mathrm{~g} / \mathrm{L}$ \\
Thrombocytaszám & $\leq 100 \times 109 \mathrm{G} / \mathrm{L}$ \\
$\beta_{2}$-microglobulin & $>3 \mathrm{mg} / \mathrm{L}$ \\
Szérum monoklonális IgM & $>70 \mathrm{~g} / \mathrm{L}$ \\
\hline
\end{tabular}

\begin{tabular}{|c|c|}
\hline Rizikóstratifikáció & $\begin{array}{l}\text { Ötéves } \\
\text { túlélés }\end{array}$ \\
\hline $\begin{aligned} \text { Alacsony rizikó } \leq & \text { l prognosztikai faktor } \\
& \text { (kivéve életkor) }\end{aligned}$ & $87 \%$ \\
\hline Közepes rizikó 2 prognosztikai faktor vagy életkor >65 év & $68 \%$ \\
\hline Magas rizikó $>2$ prognosztikai faktor & $36 \%$ \\
\hline
\end{tabular}

javult, jelenleg nyolc év körüli [21]. A 70 év alatti korcsoport ötéves túlélése lényegesen jobb, mint a 70 év fölöttieké (71\% vs. 39\%) [20]. A prognózis pontosabb meghatározására az IPSSWM-score-rendszer használható [22], bár a legújabb adatok a rendszer revíziójára szólítanak fel ( $1 A$ és $1 B$ táblázat). (Az alacsonyabb thrombocytaszám túl kisszámú beteget érint, és ezért nem prognosztikus, ugyanakkor a magasabb LDH-érték és a 75 éven felüli életkor multivariáns tesztben prognosztikusnak bizonyult [23].) A diagnózis idején a betegek körülbelül negyedének smouldering betegsége (SWM) van, amely nem okoz sem klinikai tünetet, sem vérképeltérést. Ebben a fázisban a korai terápia bevezetése nem jelent szignifikáns túlélési elönyt [24]. Az SWM tünetes betegségbe történő progressziójának aránya az idő előrehaladtával egyre nő, 15 év alatt közel 71\% [25].

\section{A WM diagnózisa és elkülönítő diagnosztikája}

A diagnosztika két alappillére a szérum-IgM monoklonális fehérje jelenléte (mennyiségtől függetlenül) és a csontvelő lymphoplasmocytás infiltrációja (egyes rendszerek szerint legalább 10\%-ban, míg mások ezt százalékban nem határozzák meg). Gyakori extramedullaris manifesztáció a lymphadenomegalia és a splenomegalia. A sejtes infiltrátum kis lymphocytákból, lymphoplasmocytoid sejtekből és plazmasejtekból áll. A típusos immunfenotípusos megjelenés a következő: felszíni IgM+, CD5+/-, CD10-, CD19+, CD20+, CD22+, CD23-, CD25+, CD27+, FMC7+, CD103-, CD138+ [1, 26].

Differenciáldiagnosztikai szempontból a Waldenström-macroglobulinaemiát fontos elkülöníteni az esetlegesen egyéb monoklonális gammopathiával bíró lymphomáktól (például CLL, margináliszóna- és köpenysejtes lymphoma), a myelomától és az MGUStól, továbbá neuropathia esetén a POEMS-szindrómától és az AL-amyloidosistól.

A diagnózishoz és stádiumfelméréshez szükséges laboratóriumi vizsgálatok a rutin-laborvizsgálatokon felül a szérum-LDH, béta-2-mikroglobulin, szérumproteinELFO és immunfixáció, szérum-szabadkönnyưláncok, immunglobulinszintek, hepatitisvírus-szerológia, vizeletüledék és fehérjeürítés meghatározása. A cristabiopszia elvégzése megkerülhetetlen. Fontos továbbá az extrame-

1B táblázat | 2017-ben javasolt prognosztikai besorolás a revideált IPSSWM alapján

\begin{tabular}{lll|ll}
\hline Prognosztikai faktorok $(1$ pont): & HR & Score & \multicolumn{1}{l}{10 éves túlélés } \\
\hline Életkor & $65-75$ év & 2,1 & 0 & $85 \%$ \\
Életkor & $\geq 75$ év +1 pont & 3,9 & 1 & $59 \%$ \\
Szérumalbumin & $\leq 35 \mathrm{~g} / \mathrm{L}$ & 1,9 & 2 & $39 \%$ \\
$\beta_{2}$-microglobulin & $>4 \mathrm{mg} / \mathrm{L}$ & 1,8 & 3 & $28 \%$ \\
Szérum-LDH & $>250 \mathrm{U} / \mathrm{L}$ & 1,7 & $4-5$ & $12 \%$ \\
\hline
\end{tabular}


2. táblázat |A Waldenström-macroglobulinaemia klinikai tünetei

\begin{tabular}{ll}
\hline $\begin{array}{l}\text { Lymphoplasmocytás } \\
\text { lymphoma okozta }\end{array}$ & $\begin{array}{l}\text { Szisztémás tünetek: láz, fogyás, éjszakai } \\
\text { tünetek: }\end{array}$ \\
& $\begin{array}{l}\text { Csontvelói infiltráció: cytopeniák } \\
\text { Hepatosplenomegalia, } \\
\text { lymphadenomegalia }\end{array}$ \\
\hline
\end{tabular}

Monoklonális IgM Hiperviszkozitás: orrvérzés, homályos látás, okozta tünetek:

dullaris tumortömeg felmérését célzó képalkotó vizsgálatok elvégzése is (hasi ultrahangvizsgálat vagy mellkashasi CT).

A klinikai tünetek szerteágazóak lehetnek, mégis két fó csapásirány mentén könnyedén megérthetők (2. táblázat). A tünetek egyik csoportját a monoklonális immunglobulin jelenlétével összefüggő jelenségek képezik, mint a hiperviszkozitás-szindróma, a Coombs-pozitív hideg haemolyticus anaemia, a perifériás neuropathia vagy a paraproteinek parenchymás szervekben történő lerakódása következtében kialakuló szervkárosodások (például amyloidosis vagy glomerulonephritis). A másik tünetcsoportot a B-sejtes lymphomáknál megszokott általános tünetek, hepatosplenomegalia, lymphadenomegalia és a csontvelő-infiltráció következtében kialakuló cytopenia képezik. A hiperviszkozitás-szindrómát és a neuropathiát e betegségben kiemelt jelentősége miatt részletesebben is tárgyaljuk.

A hiperviszkozitás-szindróma gyakori prezentációs tünet Waldenström-betegségben. A monoklonális IgM felszaporodása a szérumban jelentősen fokozza a vér viszkozitását, amely számos tünetet okozhat. A szérum IgM mennyisége és az egyes tünetek fellépése között nincs határozott összefüggés, nagyok az egyéni különbségek. A spontán megjelenő orrvérzés, a szédülés, fülzúgás, az új keletû fejfájás vagy látászavarok a leggyakoribb első tünetek. A szemfenék vizsgálata segíti a gyors diagnózist. Azonnali beavatkozás szükséges a súlyosabb tünetek, mint például a központi idegrendszeri vérzés, retinakárosodás vagy thromboticus események (például tüdőembólia, sinusthrombosis, stroke) elkerülése érdekében. A hiperviszkozitás és következményes plazmavolumennövekedés szívelégtelenség tüneteihez is vezethet, továbbá a kifejezett hiperviszkozitás zavartságot, a vigilitás csökkenését, akár kómát is okozhat. Tünetmentes IgMszint-növekedés esetén nem szükséges a WM kezelésének megkezdése. Egy nagy retrospektív tanulmány adatai szerint 61,8 g/L (31-124 g/L) volt az átlagos IgM-

érték, amelynél hiperviszkozitási tünetek jelentkeztek, és a betegek 36\%-ának voltak ennek megfelelő tünetei a WM diagnózisakor. A neves munkacsoport a $60 \mathrm{~g} / \mathrm{L}$ IgM-érték felett, tünetektől függetlenül bevezetett, preemptív terápia szükségességét szorgalmazza, megelőzve ezzel számos komplikációt [27]. A hiperviszkozitási tünetet mutató beteg mindenképpen sürgős plazmacserekezelésre szorul. Anaemia esetén a vörösvérsejt-transzfúzió adása a beavatkozás előtt lehetőleg kerülendő, mert tovább növelheti a vér viszkozitását. A vörösvérsejtmaszsza ilyenkor a plazmacsere alatt vagy közvetlenül utána adható. A teljes plazmavolumen cseréje megtörténik, amelyhez albuminszubsztitúció javasolt. A beavatkozás naponta ismételhető a tünetek megszúnéséig, általában egy-két kezelés elegendő. Fontos megjegyezni, hogy a plazmacsere-kezelés nem befolyásolja a betegség lefolyását. A malignus klón eradikálását célzó specifikus daganatellenes terápia megkezdése nélkül a tünetek néhány hét elteltével visszatérhetnek [28].

Perifériás neuropathia jelentkezése legtöbbször IgMM-proteinhez köthető, IgA- vagy IgG-M-protein jelenléte esetén kevésbé valószínú. Neuropathia a Waldenström-betegek körülbelül 20\%-ánál van jelen a diagnóziskor. A leggyakoribb eltérés a distalis, szimmetrikus és lassan progrediáló szenzomotoros perifériás neuropathia, amely paraesthesiát és izomgyengeséget okoz. Általában az alsó végtagok érintettsége kifejezettebb. Az antimyelin-asszociált glikoprotein (anti-MAG) a betegek felében kimutatható, de nincs összefüggés az antitestek jelenléte és a tünetek súlyossága között. Egyéb antitesteket is leírtak, ezek jelentősége bizonytalan. A neurológiai károsodás és a monoklonális fehérje jelenléte közötti okokozati összefüggés egyértelmű, bár a pontos patomechanizmus nem egészen ismert, az antitestek direkt demyelinizáló hatását feltételezik. A neuropathia differenciáldiagnosztikája sokszor nem egyszerú, az anamnézis mellett a fizikális vizsgálat és az EMG együttes használata segíti a helyes diagnózist. Biopszia általában nem szükséges. A neuropathiás panaszok hátterében álló egyéb tényezők - mint például diabetes mellitus, alkoholizmus vagy neurotoxikus gyógyszerek - lehetőségéről sem szabad megfeledkeznünk.

Amennyiben perifériás neuropathia és monoklonális gammopathia együttes fennállása igazolható, az MM, WM és MGUS mellett két másik, jól karakterizálható plazmasejtes betegség elkülönítése szükséges, tekintettel eltérő kezelési lehetőségeikre. A POEMS-szindróma (polyneuropathia, organomegalia, endocrinopathia, monoklonális protein, skin = bőrtünetek) a betûszó feloldásából adódó tüneteken kívül folyadékképződéssel és szklerotikus csontlaesiókkal jár, más néven osteoscleroticus myelomának is hívják. Itt a perifériás neuropathia főként motoros érintettségü, és a monoklonális protein többnyire IgA vagy IgG típusú. AL-amyloidosisban a betegek negyedében neuropathia is megjelenik, ám többnyire nem ez uralja a klinikai képet. Gyakoribb, a monoklonális lambda-könnyúlánc lerakódása következ- 
tében kialakuló, diasztolés szívelégtelenség és a nephrosisszindróma, de bél- vagy májérintettség is előfordul. Amyloidosisban a neuropathia fóként szenzoros típusú, és a gyakran társuló carpalisalagút-szindróma miatt a felső végtagok érintettsége feltűnóbb lehet. EMG/ENG vizsgálaton az amyloidneuropathia általában axonalis megjelenésű, míg a monoklonális gammopathia mellett elsősorban demyelinisatio észlelhető [29].

\section{Betegségre szabott terápia WM-ben}

A WM kezelésére - sok más ritka betegséghez hasonlóan - évtizedeken át indikáción túli alkalmazásként lymphomára és myelomára törzskönyvezett szereket és protokollokat alkalmaztunk és alkalmazunk mai napig. Ez praktikusan annyit jelent, hogy a betegek megfelelő kezelése ma Magyarországon csak külön OGYÉI-engedély birtokában lehetséges, amely jelentősen megnehezíti az ellátást. Változást ebben az „állóvízben” az ibrutinib relapsusba került WM-re történő törzskönyvezése jelentett. Időközben az is világossá vált, hogy az ibrutinib WM-ben kifejtett aktivitását jelentősen befolyásolja a MYD88- és CXCR4-mutációs státusz. Mutáns MYD88 és vad típusú CXCR4 esetén legjobb a válasz, míg CXCR4-mutáció esetén a válaszkészség alacsonyabb és lassabban is alakul ki (2. ábra). Hasonló hatást írtak le ixazomib, rituximab és dexamethason alkalmazásakor, míg carfilzomib-, rituximab- és dexamethasonterápia esetén a CXCR-mutáció kimutathatósága a terápiás vá-

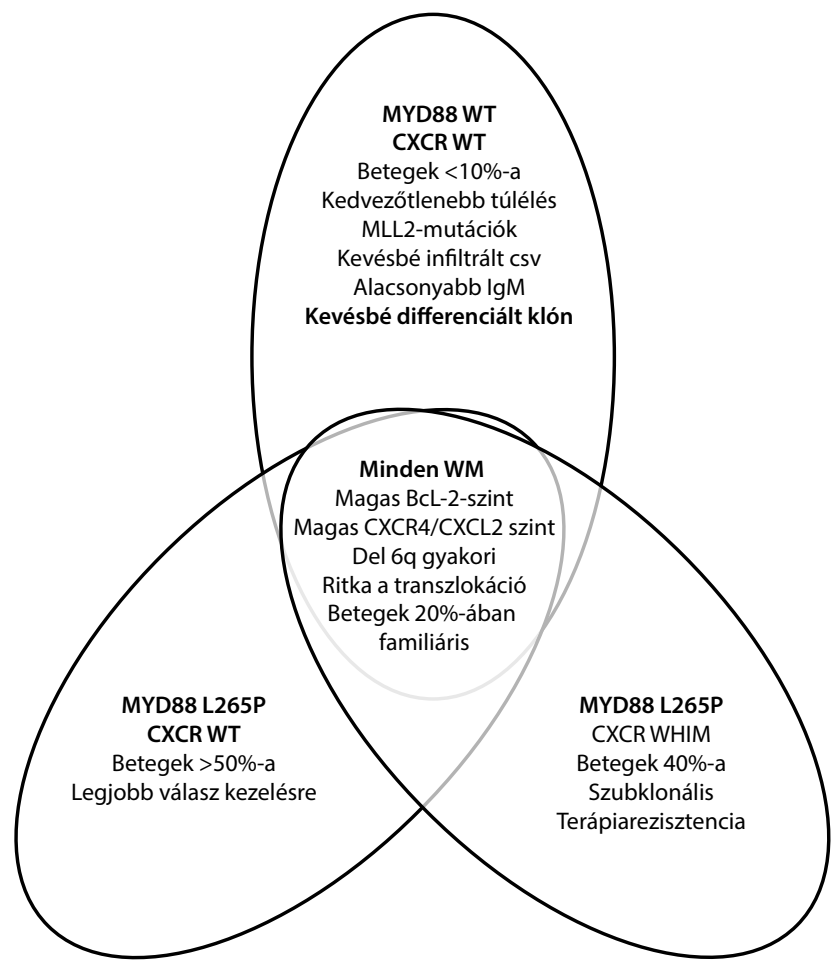

2. ábra

A Waldenström-macroglobulinaemia molekuláris tumorbiológiai tulajdonságainak és klinikumának kapcsolata az [5]-ös számú irodalom alapján
3. táblázat A kezelés megkezdésének indikációi Waldenström-macroglobulinaemiában

Hiperviszkozitási tünetek

Közepesen súlyos/súlyos perifériás polyneuropathia

AL-amyloidosis, nephropathia

Immun haemolyticus anaemia vagy immun-thrombocytopenia

Tünetet okozó cryoglobulinaemia

Tünetet okozó lymphadenomegalia, bulky tumor

Bing-Neel-szindróma

Hepato- és/vagy splenomegalia okozta panaszok

Hemoglobin $<100 \mathrm{~g} / \mathrm{L}$

Thrombocytaszám<100 G/L

Szisztémás tünetek (láz, fogyás, verítékezés)

laszt nem befolyásolta. A következőkben ismertetnénk a szerzők irodalmi adatokkal alátámasztott véleményét a WM rizikó- és betegségadaptált kezelésére vonatkozóan, a hazai lehetőségek birtokában.

\section{A Waldenström-macroglobulinaemia kezelése}

A Waldenström-macroglobulinaemia jelenleg még inkurábilis betegség, így a terápia célja a tünetek tartós csökkentése és a szervkárosodások megelőzése, a megfelelő életminőség biztosítása érdekében. Az aszimptomatikus betegek csupán ellenőrzést igényelnek, tekintve, hogy egyetlen klinikai vizsgálat sem igazolta, hogy a korán elkezdett terápia javítaná a túlélést (3. táblázat). A tünetek súlyossága, az életkor, a cytopeniák, a tumortömeg, a neuropathia jelenléte és az esetlegesen tervezett őssejttranszplantáció egyaránt befolyásolja a terápiaválasztást. Fontos, hogy az a beteg, aki autológ össejt-transzplantáció potenciális jelöltje, lehetőség szerint ne kapjon őssejttoxikus terápiát. Így a tartós orális alkilezőszer alkalmazását (például chlorambucil) vagy a nukleozidanalógokat (fludarabin, cladribin) ajánlott elkerülni a fiatalabb betegeknél, mivel ezek nemcsak őssejttoxikusak, hanem másodlagos malignitások kialakulására és a betegség transzformációjára is hajlamosíthatnak. Fontos figyelembe vennünk, hogy a myeloma kezelésével szemben WM-ben az M-protein csökkenése általában lassú, négyhat hónapot is igénybe vehet. Részleges remisszió kialakulása és a kezelés tervezett befejezése után nem ritka az elért válasz mélységének javulása, akár még további fél éven át.

\section{Első vonalbeli terápiák}

A tünetet okozó betegség kezelésére több terápiás alternatíva is elvileg rendelkezésre áll, az ibrutinib kivételével indikáción túli alkalmazásként (4. táblázat): rituximab, rituximab + alkilezőszerek (bendamustin, cyclophospha- 
4. táblázat |Gyakrabban használt kezelési protokollok Waldenström-macroglobulinaemiában

\begin{tabular}{|c|c|}
\hline Rituximab $(4 \times)$ & Rituximab $375 \mathrm{mg} / \mathrm{m}^{2}$ iv. (heti $1 \times$ ) \\
\hline \multirow[t]{3}{*}{$\operatorname{DRC}(6 \times)$} & Dexamethason $20 \mathrm{mg}$ iv. (1. nap) \\
\hline & Rituximab 375 mg/m² (1. nap) \\
\hline & $\begin{array}{l}\text { Cyclophosphamid } 100 \mathrm{mg} / \mathrm{m}^{2} \text { p. o. napi } 2 \times \\
\text { (1-5. nap) }\end{array}$ \\
\hline \multirow[t]{4}{*}{$\operatorname{BRD}(4 \times)$} & Bortezomib $1,3 \mathrm{mg} / \mathrm{m}^{2}$ s. c. $($ heti $1 \times)$ \\
\hline & Rituximab 375 mg/m² iv. (11. nap) \\
\hline & $\begin{array}{l}\text { Dexamethason } 40 \mathrm{mg} \text { iv/p. o. (1., 8., 15., } 22 . \\
\text { napokon) }\end{array}$ \\
\hline & fenntartó: további négy ciklus háromhavonta \\
\hline \multirow[t]{6}{*}{$\operatorname{CaRD}(6 \times)$} & $\begin{array}{l}\text { Carfilzomib } 20 \mathrm{mg} / \mathrm{m}^{2} \text { iv. (1-2. nap) az } 1 \text {. ciklusban, } \\
\text { majd } 36 \mathrm{mg} / \mathrm{m}^{2} \text { tovább }\end{array}$ \\
\hline & Rituximab 375 mg/m² (2. nap és 9. nap) \\
\hline & Dexamethason $20 \mathrm{mg}$ iv. (1., 2., 8., 9. nap) \\
\hline & fenntartó: nyolchetente, további nyolc ciklus \\
\hline & $\begin{array}{l}\text { Carfilzomib } 36 \mathrm{mg} / \mathrm{m}^{2} \text { iv. (1-2. nap), dexamethason } \\
20 \mathrm{mg} \text { (1-2. nap) }\end{array}$ \\
\hline & Rituximab 375 mg/m² (2. nap) \\
\hline \multirow[t]{2}{*}{$\mathrm{RB}(4 \times)$} & Bendamustin 70 mg/m² iv. (1-2. nap) \\
\hline & Rituximab 375 mg/m² iv. (1. nap) \\
\hline \multirow[t]{5}{*}{ R-CHOP (4-8×) } & Rituximab 375 mg/m² iv. (1. nap) \\
\hline & Cyclophosphamid $750 \mathrm{mg} / \mathrm{m}^{2}$ iv. (1. nap) \\
\hline & Doxorubicin $50 \mathrm{mg} / \mathrm{m}^{2}$ iv. (1. nap) \\
\hline & Vincristin $1,4 \mathrm{mg} / \mathrm{m}^{2}$ iv. (max. $\left.2 \mathrm{mg}\right)$ (1. nap) \\
\hline & Prednisolon 100 mg/m² p. o. (1-5. nap) \\
\hline \multirow[t]{2}{*}{$\mathrm{R}-\mathrm{F}(6 \times)$} & Fludarabin $25 \mathrm{mg} / \mathrm{m}^{2}$ iv. (1-5. nap) \\
\hline & Rituximab 375 mg/m² iv. (1. nap) \\
\hline \multirow[t]{3}{*}{$\mathrm{R}-\mathrm{FC}(4 \times)$} & Fludarabin $25 \mathrm{mg} / \mathrm{m}^{2}$ iv. (1-3. nap) \\
\hline & Cyclophosphamid 250 mg/m² iv. (1-3.nap) \\
\hline & Rituximab 375 mg/m² iv. (1. nap) \\
\hline Ibrutinib & $420 \mathrm{mg}$ p. o. naponta \\
\hline
\end{tabular}

mid), proteaszómagátlók (bortezomib, carfilzomib), nukleozidanalógok, az ibrutinib és az everolimus.

A rituximab-monoterápia $\left(375 \mathrm{mg} / \mathrm{m}^{2}\right.$ hetente, négy hétig ismételve) alkalmas lehet a minimális tünetekkel rendelkező, „low-risk” betegek kezelésére, mint például mérsékelt anaemia és thrombocytopenia vagy izolált IgM-asszociált neuropathia, szteroidrefrakter haemolyticus anaemia $[28,30]$. Rituximab alkalmazása megfontolandó azon betegek számára is, akik agresszívebb kemoterápiára alkalmatlanok, itt alkilezőszer-monoterápia alternatíváját jelenti. A válasz lassú, több hónapot vesz igénybe. A rituximabbal kombinált kemoterápiák hatékonyabbak és gyorsabb hatásúak, ezek alkalmazása súlyosabb cytopenia, nagy tumortömeg, konstitucionális tünetek vagy hiperviszkozitás esetén indokolt. A rituximab fenntartó terápia javítja a túlélést, de magasabb infekciós kockázata miatt általában nem javasolt [31].
A rituximab első beadásával körültekintően kell eljárni, nemcsak az infúzióval kapcsolatos ritkán előforduló allergiás reakciók veszélye miatt, hanem Waldenströmbetegségben speciálisan megfigyelhető, „IgM flair-nek” nevezett jelenség miatt is, amely a tumorsejtekben preformált immunglobulin felszabadulásával jelentősen megnövelheti a szérum viszkozitását. Definíció szerint a megnevezést $25 \%$ vagy annál nagyobb IgM-szint-növekedés esetén használjuk, amely a betegek jelentős hányadánál tüneteket okoz, hónapokig perzisztálhat, és nem jelenti a betegség progresszióját. A fentiek megelőzése céljából, magasabb IgM-szint ( $40 \mathrm{~g} / \mathrm{L}$ feletti) esetén, rituximab tervezett beadása előtt preventív célú plazmacsere elvégzése feltétlenül szükséges [28].

Első vonalban legfő́képp háromféle, rituximabbal kombinált kemoterápia javasolható, amelyek egyike sem rontja az őssejtgyújtés sikerét. Dexamethason + rituximab + cyclophosphamid (DRC), bortezomib + rituximab + dexamethason (BRD) és rituximab + bendamustin ( $\mathrm{RB})$ a választható terápiás alternatívák [32]. A válaszadási arány hasonlóan jó, az adott beteg számára leginkább megfelelő protokoll kiválasztását a klinikai kép határozza meg.

Súlyosabb neuropathiás tünetek esetén a dexamethason + rituximab + cyclophosphamid (DRC) protokoll választandó, ha dexamethason adása egyéb okból nem kontraindikált (például szívelégtelenség). A betegek 83\%-a válaszol a kezelésre, a komplett remisszió aránya 7\%. További neurotoxicitással nem kell számolnunk, és a mellékhatásprofil is igen kedvező [33]. Tekintettel a bortezomib ismerten neuropathiát okozó mellékhatására, a fenti esetekben alkalmazása kerülendő.

Ha fóképp cytopenia, hiperviszkozitás vagy egyéb IgM-asszociált tünet dominálja a klinikai képet, a bortezomib + rituximab + dexamethason (BRD) sikerrel alkalmazható. A válaszadási arány 85-96\% [34]. A kezelés leggyakoribb mellékhatásaként igen gyakran perifériás neuropathia jelentkezik, amely miatt sokszor meg kell szakítani vagy módosítani kell a terápiát. A heti egyszer adott subcutan bortezomib alkalmazásával sokkal kisebb a neurotoxicitás, mint a heti kétszeri intravénás beadás mellett. Ez a protokoll javasolható WM-hez társuló amyloidosis esetén is (esetleg dexamethasondózis-redukcióval). A BRD-kezelés okozta neuropathiás szövődmények szoros obszervációja és a kezelés mellett, illetve azt követően legalább fél éven át tartó acyclovir-herpeszprofilaxis alkalmazása feltétlenül szükséges. Amennyiben hozzáférhető, a bortezomib helyett carfilzomib is adható (CaRD), amely hasonlóan hatékony és nem okoz neuropathiát, azonban szívbetegségben alkalmazása kockázatos [35].

Nagy tumortömeg esetén az R-bendamustin- (RB-) kezelés javasolható, amely más low-grade non-Hodgkinlymphomához hasonlóan, Waldenström-betegségben is viszonylag gyors terápiás választ eredményezhet a betegek 90\%-ában [36, 37]. Relabált, refrakter betegség esetén is kiválóan alkalmazható, 83\%-os válaszadási arány 
mellett [38]. A bendamustin általában jól tolerálható terápia, még idősebb betegek esetén is. A legfontosabb mellékhatásként a neutropenia emelhető ki, amely GCSF preventív adásával legtöbbször nem okoz súlyos szövődményeket. Elhúzódó lymphopeniát okozó mellékhatása miatt herpeszellenes és Pneumocystis-profilaxis alkalmazása is ajánlott. Az R-CHOP protokoll terápiás alternatívát nyújthat, azonban toxicitása magasabb, ma már csak ritkábban jön szóba [39]. Az R-CHOP és az R-CVP alkalmazásával nem jobbak az eredmények, azonban a toxicitásuk, beleértve a vincristin okozta neuropathiát is, nem elhanyagolható [40].

A terápiás válasz értékelése standardizált módon történik. A kezelés hatékonyságát minden kemoterápiás ciklus előtt megvizsgáljuk. A komplett remisszió (CR) a monoklonális protein teljes eltünése, normális szérum-IgMszint, a lymphadenopathia, organomegalia és a csontvelői infiltráció hiánya, valamint a klinikai tünetek megszünése mellett mondható ki. Az eredményt hat hét múlva egy második immunfixációval is meg kell erősíteni. Nagyon jó parciális remisszió (VGPR) az IgM 90\%-os csökkenése esetén áll fenn, organomegalia, lymphadenomegalia és klinikai tünetek hiányában. Részleges remiszsziót (PR) 50-90\% közötti IgM-csökkenés esetén véleményezhetünk, a nyirokcsomók és organomegalia párhuzamos megkisebbedése mellett, aktív betegséget jelző klinikai tünetek hiányában. Minimális választ (MR) jelent, ha az IgM értéke csak 25-50\%-kal csökkent. Progresszív betegségről (PD) 25\%-os IgM-szint-emelkedés vagy a vérképeltérések, klinikai tünetek romlása esetén beszélhetünk. A stabil betegség (SD) kifejezést akkor használhatjuk, ha az IgM-érték nem csökkent, de nem is emelkedett 25\%-nál nagyobb mértékben, és a klinikai tünetek változatlanok. A major válasz alatt a $\mathrm{CR}, \mathrm{VGPR}$ és PR értendő [2].

65 (70?) év alatti betegek esetében az elért első remisszióban javasolható autológ őssejtek gyüjtése és cryoprezervációja, de ASCT az első vonalbeli kezelés részeként, annak konszolidációjára nem javasolható. Bár a nagy dózisú kemoterápiát követő autológ transzplantáció eredményei jók, a nemzetközi konszenzus az eljárást második vagy harmadik remisszió konszolidációjára javasolja elsősorban [28].

\section{A relabált betegek kezelése}

Tekintve, hogy nem gyógyítható, krónikus betegséggel állunk szemben, a relapsus idővel elkerülhetetlen. Egykét éves remissziót követően a kezdetben sikerrel alkalmazott terápia újra megkísérelhető. Korai relapsus/ progresszió vagy refrakter betegség esetén másik terápiás alternatíva választandó. Ilyenkor bármelyik, a fent említett, első vonalban javasolt és még nem alkalmazott terápia sikerrel adható, továbbá lehetőség van az ibrutinib alkalmazására is $[41,42]$. Remisszióba jutott betegnél mérlegelhető az autológ őssejtátültetés lehetősége, mint konszolidációs kezelés, különös tekintettel, ha már ren- delkezünk legyűjtött őssejtekkel. Relabált, refrakter betegek ellátásánál jön szóba a purin-nukleozidanalógok (fludarabin, cladribin) alkalmazása is, amennyiben autológ transzplantációt nem tervezünk (vagy őssejteket már gyújtöttünk).

A fludarabint és cladribint monoterápiában és rituximabbal kombinálva egyaránt alkalmazhatjuk. A rituximab növeli a válaszadási arányt, elhanyagolható hozzáadott toxicitás ellenében. A rituximab + fludarabin (R-F) kezeléssel 95\%-os válaszadási arány érhető el, de számolni kell a fludarabin okozta súlyos toxicitással, mint a thrombopenia, neutropenia, infekciók, valamint megnövekedett a kockázat MDS/AML későbbi kialakulására [43]. Az R-FC kezelés (fludarabin, rituximab, cyclophosphamid) igen hatékony terápia lehet Waldenströmbetegségben, előrehaladott és refrakter betegségben is gyors betegségkontrollt eredményez, valamint a válaszadási arány is magas (75-79\%), azonban súlyos toxicitása miatt csak válogatott esetekben, óvatossággal alkalmazható [44]. A 70 év feletti fitt, de ASCT-re alkalmatlan relabált betegek lehetnek a nukleozidanalóg-tartalmú terápia jelöltjei, dózisredukció mérlegelésével.

Az ibrutinib fontos új terápiás lehetőség a relabált, refrakter WM-betegek kezelésében [42, 45]. A gyógyszer egy orálisan alkalmazható, irreverzibilis és szelektív, Bruton-tirozinkináz-gátló, amely a B-sejt-szignáltranszdukciós útvonal kezdetén fejt ki gátlóhatást és a B-sejtek apoptózisát okozza. Nem őssejttoxikus és nincsenek neuropathiás mellékhatások, így hosszú távú terápiára is alkalmas lehet. Mellékhatásprofil szempontjából jelentős az infekciós kockázat, a cytopenia, a hasmenés, az arrhythmiák és a vérzési rizikó emelkedése (szimptomatikus WM-ben a vérzéses tünetek kezelés nélkül is kifejezetten gyakoriak). Az ibrutinib okozta hasmenés általában átmeneti, ritmuszavarként leggyakrabban pitvarfibrilláció jelentkezik. Antikoagulációs vagy thrombocytaaggregáció-gátló kezelés mellett nem alkalmazható, mert a gyógyszer thrombocytadiszfunkciót okoz (ez a polimorbid idős WM-populációban problémát jelenthet). A legtöbb gondot a súlyos infekciók okozzák. Más indikációban alkalmazott ibrutinibterápia mellett magunk is tapasztaltunk fonalasgomba-fertőzéseket, illetve egyéb, nehezen kezelhető infekciókat. A gyógyszer felfüggesztése, immunglobulin-pótlás és széles spektrumú antibiotikus kezelés sokszor nem megkerülhető. Tanácsos tapasztalt infektológus segítségét is kérni a betegek megfelelő ellátásához.

$\mathrm{Az}$ ibrutinib alkalmazását monoterápiában engedélyezték, kombinált terápiaként még klinikai vizsgálat keretein belül tesztelik. Monoterápiára a relabált, refrakter betegek is igen jól válaszolnak. A terápiás válasz átlagosan két hónap alatt megkezdődik, de ez csak M-proteinszintű válasz, a csontvelőkép javulása éves távlatban várható, morfológiai komplett remisszió nélkül. A major válaszadási arány $73 \%$ körüli, komplett immunkémiai remisszió azonban nem érhető el [46]. Kimutatták, hogy a legtöbbet a MYD88-mutációt hordozó és CXCR4 vad 
típussal rendelkező betegek profitálnak az ibrutinibkezelésből. Ennél kicsit gyengébbek az eredmények (mind a válasz mértéke, mind annak kialakulási sebessége tekintetében), ha a MYD88 és a CXCR egyaránt mutáns. MYD88-mutáció hiányában azonban már igen szerény a válaszadási arány, így az ibrutinib-monoterápia nem javasolt [45]. Az ibrutinib hatékonysága a folyamatos adagolás függvénye, abbahagyásakor a betegség relapsusa általában gyors. Jelenleg az ibrutinib alkalmazását a gyógyszer hozzáférhetősége, folyamatos terápia szükségessége és annak költsége jelentősen korlátozza, hazánkban egyedi méltányossági eljárás kapcsán férhetünk hozzá, relapsusban.

$\mathrm{Az}$ őssejt-transzplantációt régebben salvage-terápiaként tartották számon ebben a betegségben, a többszörösen relabált vagy primer refrakter betegeknél [47]. Az allogén őssejtátültetésre igen ritkán kerül sor, tekintettel a magas, nem relapsus okozta mortalitási arányra, függetlenül attól, hogy myeloablativ vagy csökkentett intenzitású kondicionálást alkalmaztak. Az autológ őssejttranszplantáció (ASCT) azonban reális cél lehet egy nehezen kezelhető betegségben jó állapotú és nem túl idős betegek számára. ASCT esetén a nem relapsus okozta egyéves mortalitás igen alacsony, mindössze $4 \%$. A többszörösen relabált, refrakter betegcsoportban $40 \%$ os ötéves progressziómentes túlélés, valamint 69\%-os átlagos túlélés érhető el [48]. Feltételezhető, hogy a myelomához hasonlóan, a transzplantáció megfelelő időzítésével, nehézségekkel, de remisszióba került betegek konszolidációs kezeléseként használva azt, a fentieknél sokkal jobb eredményekre számíthatunk - a Mayo Klinika ajánlása [28] mellett saját adataink is erre utalnak [49]. A transzplantációt követő remisszió hossza általában jelentős, a myelománál szokásos progressziómentes túlélésnél szignifikánsan hosszabb. A WM-ben alkalmazott autológ transzplantációt követően a szupprimált IgG- és IgA-szintek normalizálódása akár több évet is igénybe vehet, az elhúzódó humorális immunhiány fokozott infekciós rizikójával. A transzplantációs megközelítés és megfelelő helyének igazolása még további vizsgálatokat igényel.

Sokszorosan előkezelt, szokásos terápiás lehetőségeit kimerítő, de általános állapota alapján kezelhető betegeink számára a klinikai vizsgálatokban való részvétel ajánlott, ha van ilyen aktuális lehetőség. A jelenleg WM-ben vizsgálat alatt álló szerek közül az everolimus, a copanlisib és a venetoclax más betegségekben már törzskönyvezett, így indikáción túl WM-ben történő alkalmazásuk indokolt lehet $[5,50]$. Elesett általános állapotú, idős betegek palliatív kezelésére a plazmaferézissel kombinált alkilezőszer-monoterápia jó választás lehet.

\section{Következtetések}

A WM diagnosztikája és kezelése a közelmúltban forradalmi mértékú változássorozaton ment át. Idős betegeket érintő, más betegcsoport „levetett” gyógyszereit döntően palliatív ellátás során hasznosító betegcsoportból egy izgalmas tumorbiológiájú és célzottan eredményesen kezelhető betegséggé vált, jelentős 10 éves túléléssel. A teljes gyógyulás ma még ritka kivétel ebben a betegségben, de újabb és újabb gyógyszerek, valamint a transzplantációs megközelítés, reményeink szerint, a közeljövőben kifejlesztendő intelligens kombinációs alkalmazásával (indukció-transzplantáció-konszolidáció?) mind nagyobb számú betegünk éri majd el a tartós betegségmentességet, a gyógyulást.

Anyagi támogatás: A közlemény megírása anyagi támogatásban nem részesült.

Szerzôi munkamegosztás: Sz. Zs.: A kéziratot írta, szerkesztette. M. G.: A koncepciót létrehozta, a kéziratot írta, szerkesztette. A cikk végleges változatát mindkét szerző elolvasta és jóváhagyta.

Érdekeltségek: A szerzőknek nincsenek érdekeltségeik.

\section{Irodalom}

[1] Tímár B. The pathology and genetic background of lymphoplasmacytic lymphoma/Waldenström macroglobulinaemia. [A lymphoplazmocitás limfóma/Waldenström-makroglobulinémia patológiája és genetikája.] Magy Onkol. 2017; 61: 6-11. [Hungarian]

[2] Mucsi OA, Nagy Zs. How can we treat Waldenström's macroglobulinemia? [Újdonságok a Waldenström-makroglobulinémia kezelésében.] Magy Onkol. 2017; 61: 12-20. [Hungarian]

[3] Hanzis C, Ojha RP, Hunter Z, et al. Associated malignancies in patients with Waldenström's macroglobulinemia and their kin. Clin. Lymphoma Myeloma Leuk. 2011; 11: 89-92.

[4] Treon SP, Tripsas C, Hanzis C, et al. Familial diasease predisposition impacts treatment outcome in patients with Waldenström macroglobulinemia. Clin Lymphoma Myeloma Leuk. 2012; 12: $433-437$

[5] Hunter ZR, Yang G, Xu L, et al. Genomics, signaling and treatment of Waldenström macroglobulinemia. J Clin Oncol. 2017; 35: 994-1001.

[6] Ocio EM, Schop RF, Gonzales B, et al. 6q deletion in Waldenström macroglobulinemia is associated with features of adverse prognosis. Br J Haematol. 2007; 136: 80-86.

[7] Avet-Loiseau H, Garand R, Lodé L, et al. 14q32 Translocations discriminate IgM multiple myeloma from Waldenstrom's macroglobulinemia. Semin Oncol. 2003; 30: 153-155.

[8] Hunter ZR, Xu L, Yang G, et al. The genomic landscape of Waldenström macroglobulinemia is characterized by highly recurring MYD88 and WHIM-like CXCR4 mutations, and small somatic deletions associated with B-cell lymphomagenesis. Blood 2014; 123: 1637-1646.

[9] Treon SP, Xu L, Yang G, et al. MYD88 L265P somatic mutation in Waldenström's macroglobulinemia. N Engl J Med. 2012; 367: 826-833.

[10] Lin SC, Lo YC, Wu H. Helical assembly in the MyD88:IRAK4: IRAK2 complex in TLR/IL-1R signaling. Nature 2010; 465: 885-890.

[11] Treon SP, Xu L, Hunter Z. MYD88 mutations and response to ibrutinib in Waldenström's macroglobulinemia. N Engl J Med. 2015; 373: 584-586. 
[12] Poulain S, Boyle EM, Roumier C, et al. MYD88 L265P mutation contributes to the diagnosis of Bing Neel syndrome. Br J Haematol. 2014; 167: 506-513.

[13] Treon SP, Tsakmaklis N, Meid K, et al. Mutated MYD88 zygosity and CXCR4 mutation status are important determinants of ibrutinib response and progression free survival in Waldenstrom's macroglobulinemia. Blood 2016; 128: 2984.

[14] Treon SP, Cao Y, Xu L, et al. Somatic mutations in MYD88 and CXCR4 are determinants of clinical presentation and overall survival in Waldenström macroglobulinemia. Blood 2014; 123 : 2791-2796.

[15] Poulain S, Roumier C, Venet-Caillault A, et al. Genomic landscape of CXCR 4 mutations in Waldenström macroglobulinemia. Clin Cancer Res. 2016; 22: 1480-1488.

[16] Liu Q, Chen H, Ojode T, et al. WHIM syndrome caused by a single amino acid substitution in the carboxy-tail of chemokine receptor CXCR4. Blood 2012; 120: 181-189.

[17] Xu L, Hunter ZR, Tsakmaklis N, et al. Clonal architecture of CXCR4 WHIM-like mutations in Waldenström macroglobulinaemia. Br J Haematol. 2016; 172: 735-744.

[18] Cao Y, Hunter ZR, Liu X, et al. The WHIM-like CXCR4 ${ }^{\mathrm{S} 338 \mathrm{X}}$ somatic mutation activates AKT and ERK and promotes resistance to ibrutinib and other agents used in the treatment of Waldenstrom's macroglobulinemia. Leukemia 2015; 29: 169-176.

[19] Alonso S, Jimenez C, Alcoceba M, et al. Whole-exome sequencing of Waldenström macroglobulinemia transformation into agressive lymphoma. Blood 2016; 128: 4101.

[20] Sekhar J, Sanfilippo K, Morgensztern D, et al. Waldenström macroglobulinemia: a Surveillance, Epidemiology, and End Results database review from 1988 to 2005. Leuk Lymphoma 2012; 53 : $1625-1626$

[21] Castillo JJ, Olszewski AJ, Kanan S, et al. Overall survival and competing risks of death in patients with Waldenström macroglobulinaemia: an analysis of the Surveillance, Epidemiology and End Results database. Br J Haematol. 2015; 169: 81-89.

[22] Morel P, Duhamel A, Gobbi P, et al. International prognostic scoring system for Waldenström macroglobulinemia. Blood 2009; 113: 4163-4170

[23] Kastritis E, Gavriatopulou M, Kyrtsonis MC, et al. A revised staging system for Waldenström's macroglobulinemia. EHA Oral Presentation 2017, Abstract S415. learnincenter.ehaweb. org/eha/2017/22nd/181702/efstathios.kastritis.a.revised. staging.system.for.waldenstrm.s.macroglobulinemia.html

[24] Dimopoulos MA, Kastritis E, Owen RG, et al. Treatment recommendations for patients with Waldenström macroglobulinemia (WM) and related disorders: IWWM-7 consensus. Blood 2014; 124: 1404-1411.

[25] Kyle RA, Treon SP, Alexanian R, et al. Prognostic markers and criteria to initiate therapy in Waldenstrom's macroglobulinemia: Consensus Panel Recommendations from the Second International Workshop on Waldenstrom's Macroglobulinemia. Semin Oncol. 2003; 30: 116-120.

[26] Owen RG, Treon SP, Al-Katib A, et al. Clinicopathological definition of Waldenstrom's macroglobulinemia: Consensus Panel Recommendations from the Second International Workshop on Waldenstrom's Macroglobulinemia. Semin Oncol. 2003; 30: $110-115$

[27] Gustine JN, Meid K, Dubeau T, et al. Serum IgM level as predictor of symptomatic hyperviscosity in patients with Waldenström macroglobulinaemia. Br J Haematol. 2017; 177: 717-725.

[28] Kapoor P, Ansell SM, Fonseca R, et al. Diagnosis and management of Waldenström macroglobulinemia. MAYO stratification of macroglobulinemia and risk-adapted therapy (mSMART) guidelines 2016. JAMA Oncol. 2017 Jan 5. DOI: 10.1001/ jamaoncol.2016.5763. [Epub ahead of print]
[29] Chaudhry HM, Mauermann ML, Rajkumar SV. Monoclonal gammopathy-associated peripheral neuropathy: diagnosis and management. Mayo Clin Proc. 2017; 92: 838-850.

[30] Ansell SM, Kyle RA, Morice WG, et al. Diagnosis and management of Waldenström macroglobulinemia: Mayo stratification of macroglobulinemia and risk-adapted therapy (mSMART) guidelines. Mayo Clin Proc. 2010; 85: 824-833.

[31] Treon SP, Hanzis C, Hunter ZR, et al. Maintenance rituximab is associated with improved clinical outcome in rituximab naïve patients with Waldenstrom macroglobulinaemia who respond to a rituximab-containing regimen. Br J Haematol. 2011; 154: 357362.

[32] Oza A, Rajkumar SV. Waldenstrom macroglobulinemia: prognosis and management. Blood Cancer J. 2016; 6: e391.

[33] Dimopoulos MA, Anagnostopoulos A, Kyrtsonis MC, et al. Primary treatment of Waldenstrom macroglobulinemia with dexamethasone, rituximab, and cyclophosphamide. J Clin Oncol. 2007; 25: 3344-3349.

[34] Treon SP, Ioakimidis L, Soumerai JD, et al. Primary therapy of Waldenström macroglobulinemia with bortezomib, dexamethasone, and rituximab: WMCTG clinical trial 05-180. J Clin Oncol. 2009; 27: 3830-3835.

[35] Treon SP, Tripsas CK, Meid K, et al. Carfilzomib, rituximab, and dexamethasone (CaRD) treatment offers a neuropathy-sparing approach for treating Waldenström's macroglobulinemia. Blood 2014; 124: 503-510.

[36] Rummel MJ, Al-Batran SE, Kim SZ, et al. Bendamustine plus rituximab is effective and has a favorable toxicity profile in the treatment of mantle cell and low-grade non-Hodgkin's lymphoma. J Clin Oncol. 2005; 23: 3383-3389.

[37] Olszewski AJ, Chen C, Gutman R, et al. Comparative outcomes of immunochemotherapy regimens in Waldenström macroglobulinaemia. Br J Haematol. 2017 Jul 5. DOI: 10.1111/ bjh.14828. [Epub ahead of print]

[38] Treon SP, Hanzis C, Tripsas C, et al. Bendamustine therapy in patients with relapsed or refractory Waldenström's macroglobulinemia. Clin Lymphoma Myeloma Leuk. 2011; 11: 133-135.

[39] Rummel MJ, Niederle N, Maschmever G, et al., on behalf of the Study group indolent Lymphomas (StiL). Bendamustine plus rituximab versus $\mathrm{CHOP}$ plus rituximab as first-line treatment for patients with indolent and mantle-cell lymphomas: an open-label, multicentre, randomised, phase 3 non-inferiority trial. Lancet 2013; 381: 1203-1210.

[40] Ioakimidis L, Patterson CJ, Hunter ZR, et al. Comparative outcomes following CP-R, CVP-R, and CHOP-R in Waldenström's macroglobulinemia. Clin Lymphoma Myeloma 2009; 9: 62-66.

[41] Oza A, Rajkumar SV. Waldenstrom macroglobulinemia: prognosis and management. Blood Cancer J. 2015; 5: e394.

[42] Paludo J, Abeykoon JP, Kumar S, et al. Dexamethasone, rituximab and cyclophosphamide for relapsed and/or refractory and treatment-naïve patients with Waldenstrom macroglobulinemia. Br J Haematol. 2017; 179: 98-105.

[43] Treon SP, Branagan AR, Ioakimidis L, et al. Long-term outcomes to fludarabine and rituximab in Waldenström macroglobulinemia. Blood 2009; 113: 3673-3678.

[44] Tedeschi A, Benevolo G, Visco C, et al. Fludarabine plus cyclophosphamide and rituximab in Waldenstrom macroglobulinemia: an effective but myelosuppressive regimen to be offered to patients with advanced disease. Cancer 2012; 118: 434-443.

[45] Treon SP, Tripsas CK, Meid K, et al. Ibrutinib in previously treated Waldenström's macroglobulinemia. N Engl J Med. 2015; 372: 1430-1440.

[46] Abeykoon JP, Yanamandra U, Kapoor P. New developments in the management of Waldenström macroglobulinemia. Cancer Manag Res. 2017; 9: 73-83.

[47] Treon SP. How I treat Waldenström macroglobulinemia. Blood 2015; 126: 721-732. 
[48] Kyriakou C, Canals C, Sibon D, et al. High-dose therapy and autologous stem-cell transplantation in Waldenström macroglobulinemia: the Lymphoma Working Party of the European Group for Blood and Marrow Transplantation. J Clin Oncol. 2010; 28: 2227-2232.

[49] Mikala G, Ceglédi A, Csukly Z, et al. High-dose therapy fallowed by autologous stem cell transplantation is an exceptionally effective therapy in Waldenström's macroglobulinemia [A nagy dózisú terápiát követő autológ őssejt-átültetés a Waldenström macroglobulinemia kiemelkedően eredményes terápiás lehetősége. Hematol Transzfúz. 2016; 49: S56. [Hungarian]
[50] Paulus A, Akhtar S, Yousaf H, et al. Waldenstrom macroglobulinemia cells devoid of $B T K^{C 48 I S}$ or $C X C R^{\text {WHIM-like }}$ mutations acquire resistance to ibrutinib through upregulation of $\mathrm{Bcl}-2$ and AKT resulting in vulnerability towards venetoclax or MK2206 treatment. Blood Cancer J. 2017; 7: e565.

(Mikala Gábor dr., Budapest, Albert Flórián út 5-7., 1097 e-mail: gmikala@laszlokorhaz.hu)

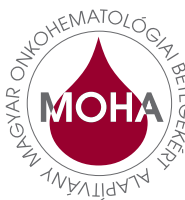

A Magyar Onkohematológiai Betegekért Alapítvány (MOHA) közhasznú civil szervezet, mely azért jött létre, hogy segítse a vérképzöszervi betegségekkel kuizdő érintettek hiteles tájékoztatását, érzelmi támogatást nyújtson számukra és képviselje érdekeiket a mindenkori döntéshozók elött.

\section{BETEGEDUKÁCIÓ}

A hematológiai betegségekkel és korszerú kezelési lehetőségekkel kapcsolatos általános, közérthető tájékoztatásban segítjük az érintetteket a legkiválóbb szakemberek bevonásával. Kifejezett célunk a bizonyítékokon alapuló orvoslás iránti bizalom megerósítése és a természettudományos gondolkodás népszerúsítése.

\section{PSZICHOSZOCIÁLIS TÁMOGATÁS}

Támogató csoportjaink célja - az ismeretterjesztésen túl a hasonló problémával küzdő betegek és családtagjaik összefogása, érzelmi támogatása, a bizalmon alapuló orvosbeteg kapcsolat erősítése. A csoporton belül lehetőség van találkozni olyan sorstársakkal, akiknek a példája segítséget nyújthat a sikeres megküzdéshez, a velük való ossinte beszélgetés oldhatja a betegség és a kezelések miatt érzett szorongást.

\section{ÉRDEKÉRVÉNYESÍTÉS}

A MOHA célja, hogy minden érintett megkapja a betegségére ajánlott legkorszerúbb kezelést. Míg az egyes betegek kevéssé tudnak hatékonyan fellépni érdekeik védelmében, addig összefogással, civil nyomásgyakorlással sikert érhetünk el. Az orvostudomány fejlődésének köszönhetően folyamatosan jelennek meg az új terápiák, amelyek további esélyt adnak a betegeknek. Fontos, hogy az érintettek tudjanak az új lehetőségekről és konzultáljanak arról kezelőorvosukkal! Célunk, hogy a betegek a szükséges gyógyszerekhez minél egyszerúbben, kiszámíthatóan és átláthatóan juthassanak hozzá a megfelelő időben, ezért elvárásunk, hogy az európai gyakorlathoz hasonlóan a betegekkel kapcsolatos döntéshozói folyamatokba vonják be a betegszervezetek képviselőit is.

\section{ELÉRHETŐSÉGEINK}

Magyar Onkohematológiai Betegekért Alapítvány moha@onkohemat.hu,+36204398645 www.onkohemat.hu, www.facebook.com/onkohemat.hu

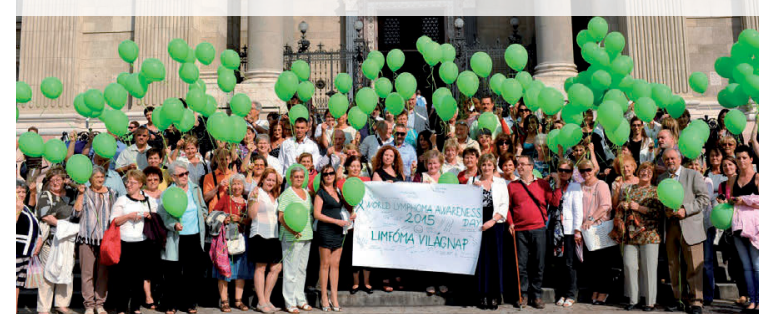

